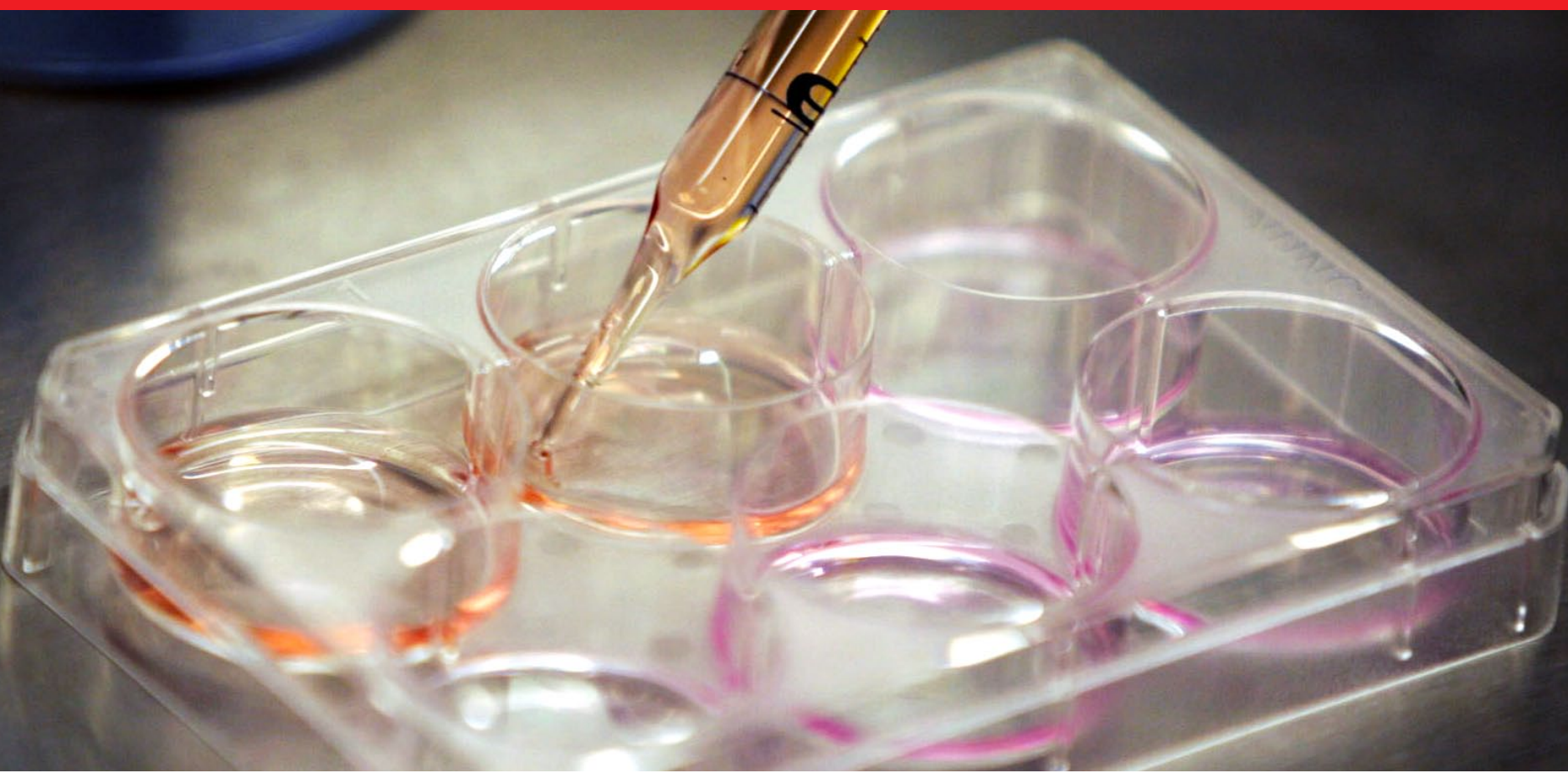

\title{
FAST AND FURIOUS
}

\section{疾走するiPS 細胞研究}

Nature Vol. 458(962-965)/23 April 2009

iPS 細胞の研究はスタートして 3 年あまりが経過し、まさに疾走・爆走状態となっている。Monya Bakerが、これまでの経過 と今後の課題をさぐる。

2007 年初春、山中伸弥. 京都大学教授 は、iPS 細胞（人工多能性幹細胞）の研 究レースで、余裕をもって好スタートが切 れたと感じていた。ありふれたマウスの体 細胞から ES 細胞（胚性幹細胞）によく似 た細胞を世界で初めて作製し1、まだ半年 も経っていなかった。山中の成果に対し ては、畏敬の念と疑念が相半ばしていた。 それでも、細胞のアイデンティティーがこ れほど柔軟に変化すること、具体的には、 わずか 4 種類の胚性遺伝子を挿入するだ けで、ほぼすべての体組織に分化しうる細 胞に再プログラム化できることを、心から 信じる者は当時ほとんどいなかった。

山中たちが樹立した細胞が正真正銘の 多能性細胞であるためには、これがどんな 種類の細胞にも分化でき、したがって、精 細胞や卵細胞の形成にも寄与し、新たな 世代の動物の発生に関与しうることを示さ
なければならない。多くの人々に納得して もらうためには、さらに成果を積み重ねる 必要があることは、山中自身にもわかって いた。そして実際、山中は、作製方法に 改良を加えて 2007 年 6 月 6 日に次の論 文を発表した ${ }^{2}$ 。彼にとって予想外だった のは、同じ日に別の 2 つの研究室が同じ 成果を発表したことだった ${ }^{3,4}$ 。「最初の論 文発表から 10 か月足らずのことだったの で、ものすごく驚きました。同時にとても 恐ろしくなりました」と当時を思い起こす。

2006 年の 8 月にiPS 細胞という研究 分野を開拓した時、この研究に携わって いたのは、京都大学の山中の研究室だけ だった。しかしその後、Addgene 社（米 国マサチューセッツ州ケンブリッジ）が製 造する再プログラム化用の各種ベクター製 品に対して、実に 1000 以上の研究室か ら 6000 件以上の注文が寄せられた。ハー
バード大学は、トロント大学や京都大学 と同様、iPS 研究の専用施設を設立した。 こうして現在（2009 年）は、研究がさら に急ピッチで進展し、競争もさらに激化す ると予想されている。この 3 月だけでも、 再プログラム化技術の大きな改良を報告 する 4 本の論文が Nature、Cell、Science に掲載されている ${ }^{5-8}$ 。

研究を加熱させる iPS 細胞のメリット こうした熱気には無理からぬ事情がある。 iPS 細胞では、ES 細胞と同じ幹細胞治療. 薬剂スクリーニング・疾患モデルの作製な どができ、しかも ES 細胞に伴う倫理的・ 技術的問題の大半を回避できるとみられ ているからだ。初期のヒト ES 細胞研究の 多くは、ヒトの胚を入手できる科学者だけ が進めていた、とシェフィールド大学（英 国）の幹細胞科学者 Peter Andrews は 
指摘する。それが iPS 技術の発明によって 「有能な分子生物学者や細胞生物学者で あれば誰でも参入できる研究分野になっ た」のだ。1981 年に初めてマウス ES 細 胞が単離されてからヒト ES 細胞の単離ま でに 17 年の歳月を要したが、iPS 細胞の 場合、マウスからヒトまで、わずか 15 か 月だった。注目すべきことは、患者と適合 するヒトES 細胞は作られていないが、iPS 細胞では、既にそれに相当する目標が達 成されている点だ。糖尿病、ハンチントン 病、筋ジストロフィー症の患者から iPS 細 胞が作られているのである ${ }^{9}$ 。

次の目標は、より多くの疾患に対して疾 患特異的 iPS 細胞を作製することであり、 より安全でより効率の高い作製法を開発 することである。この明確な目標に向かっ て、生物学者はしのぎを削っているわけ だ。しかし「この状況は健全ではありま せん。過熱しすぎです。研究室では、来 る日も来る日も、先を越されないかびく びくしているんですから」。こう話すのは、 ES 細胞とiPS 細胞研究の第一人者である ホワイトヘッド生物医学研究所(米国マ サチューセッツ州ケンブリッジ） の Rudolf Jaenisch だ。研究者は準備もそこそこに
論文を大急ぎで発表し、成果を共有するこ とには消極的である。「どの研究者も似た ような研究をしているため、投稿した論文 や印刷中の論文について、あまりオープ ンな話をしません」と Jaenisch は話す。

その結果、「再プログラム化の作用機 構や、再プログラム化された細胞の正確 な治療効果など、重大な問題点を見失う おそれがあります」とスクリプス研究所再 生医学センター（米国カリフォルニア州ラ ホーヤ）の Jeanne Loring センター長は 警告する。「細胞を作製することが終着点 なのではありません。新たな知見が得ら れないなら、そんな細胞に価値はないこ とを知るべきです」と Loring。

ヒトの疾患研究と治療に関して、iPS 細 胞は、ES 細胞よりもはるかに有用なも のとなる可能性が高い。iPS 細胞を使え ば、究極的には、患者の体から細胞を取 り出し、それを処理して治療用細胞に変 え、拒絶反応のリスクなしに同じ患者の 体内に戻す方法が考えられるからだ。既 に、筋萎縮性側索硬化症、脊髄性筋萎縮 症などの神経変性疾患の患者から作製さ れたiPS 細胞がニューロンに転換されてい る $^{10,11}$ 。マウスの実験では、その先の段

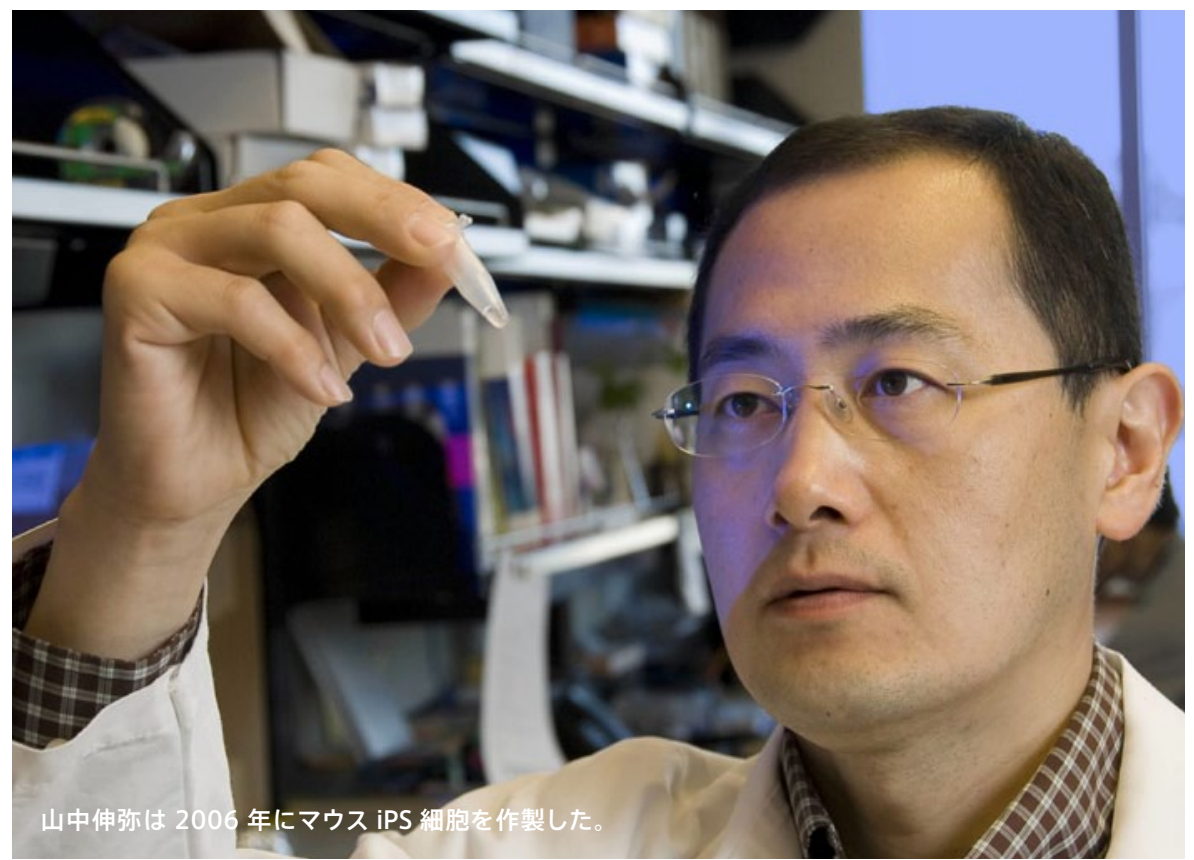

階に進んでおり、血液細胞や神経細胞が 作製され、それを利用して、鎌状赤血球 貧血とパーキンソン病のマウスモデルの症 状が改善された ${ }^{12,13}$ 。一方の疾患研究の 面では、より直接的な恩恵が期待される。 例えば脳や心臓疾患の研究者は、厳密な 実験を行うには十分な量の組織を生検や 死体から得なければならないが、もちろ ん現実には限りがある。しかし、患者から 作製されたiPS 細胞であれば、供給量に 制限はなく、シャーレで疾患過程の研究が できると期待されているわけだ。

\section{より安全で効果的な作製法をめざして}

しかし当初の 2 年間、研究者は、iPS 細胞 の作製法の改良にかかりっきりだった。山 中は、ウイルスを用いて遺伝子を成体細 胞のゲノムに挿入し、成体細胞の再プログ ラム化に必要な遺伝子を探索した。具体 的には、ES 細胞で発現する 24 種類の遺 伝子を使って実験を進め、4 種類の遺伝子 （c-Myc、KIf4、Oct4、Sox2）を突き止めた。 細胞が多能性を備えると、こうした遺伝子 の活性は弱まるが、一方で、遺伝子の挿 入により、iPS 細胞には ES 細胞よりも予想 外のことが起こりやすくなり、危険性も高 まると考えられている。例えば、がん遺伝 子 c-Myc を使って再プログラム化された細 胞をマウス胚に組み込んだ実験では、マウ スはがんを発症して死んだ1。また、山中 の未発表研究では、c-Mycを使わずに再 プログラム化された細胞から作製したマウ スは、寿命が短くなることが示されている。

より安全性が高く、より効果的な細胞再 プログラム化の方法を開発するための研 究が急ピッチで進められている。それに 伴い、傑出した研究論文も相次いで発表 されることが多くなった（p.14「画期的 な研究成果」参照)。研究の目標は、ゲ ノム損傷の危険を伴う遺伝子挿入をせず に、細胞の再プログラム化を達成すること だ。去る 3 月、複数の研究グループが、 役目を終えた再プログラム化用遺伝子を 切除する方法を発表したが、その1つが 
Jaenisch をリーダーとする研究グループ だった ${ }^{7}$ 。の 3 週間後には、ウィスコン シン大学マディソン校の James Thomson らが、遺伝子挿入を全く必要としない方 法で、ヒト細胞の再プログラム化に成功 し、Scienceに報告した 8 。これは、染色 体に組み込まれないプラスミドという環状 DNA を使って、多能性遺伝子を細胞に組 み込む方法である。

それでも、さらにすぐれた方法をめざし て、研究は続けられている。現在の再プ ログラム化の方法では、細胞が、生理的 に正常な状態から相当にかけ離れた状態 に無理やり変えられている可能性があり、 細胞が病的状態に陥ることを研究者は心 配している。再プログラム化の過程では、 腫瘍抑制経路が阻害され、発がん経路が 活性化される、とスクリプス研究所の化学 者 Sheng Ding は説明する。また、この 過程では、遺伝子の活性化を個別的に制 御する「エピジェネティックな」目印をつ ける細胞過程も阻害される。「細胞は、非 常にストレスのかかる条件下に置かれて います。それなのに、この隠れた問題が 議論されていないのです」とDing は言う。

Ding をはじめ多くの研究者は、現在の 方法を改良して、多能性状態へゆるやか に移行させる研究を進めている。その中 から、薬剂に近い分子を添加し、また、 特定のタイプの細胞に絞って再プログラム 化を行うことで、再プログラム化に使用す る遺伝子のタイプと数が減らせること、再 プログラム化率を上げられることがわかっ た。2009 年末までには、再プログラム化 用遺伝子を全く使わず、その代わりに小 型の分子とタンパク質を組み合わせて使用 し、iPS 細胞を作製する方法が複数発表さ れるだろう、と多くの研究者は予想する。

それでも、治療目的に使う細胞の安全 性を確保するには不十分だ、とThomson は言う。どのような方法による場合でも、 再プログラム化には、突然変異や厄介な エピジェネティック変化の危険性がある。 「再プログラム化を化学的に行うか、遺
伝学的に行うかにかかわらず、作製され た細胞のゲノムを徹底的に調べなければ ならないのです」とThomsonは話す。 この点は山中も同じ考えで、次のように説 明する。「iPS 細胞を作る時に使う遺伝因 子の数を減らし、あるいはゼ口にして、そ の代わりに化学物質を使えば、iPS 細胞 の安全性が高まると誰もが考えがちです が、本当にそうなのかどうかはわかりませ ん。結局は 1 つ 1 つのクローンを調べな ければならないのです。iPS 細胞を誘導す る方法を改良するのは大事ですが、確立 されたiPS 細胞の評価法の方がはるかに 重要なのです。この点は、いくら強調して もしすぎることはないと思います」。

研究ターゲットがこの種の評価法にシフ 卜を始めるだろう、と研究者は予想する。 「いろいろな方法を比較して、最もうま くいく方法を採用することになると思いま す」とハーバード幹細胞研究所の Konrad Hochedlinger。ただし “最良の方法”は、 用途によって異なると考えられる。再プロ グラム化用遺伝子の挿入による iPS 細胞 作製法は、所要時間が短く、技術的難易 度も低い。したがって、他の再プログラム 化法を持たない研究室であれば、当然、 選択肢の 1 つとして残るであろう。

\section{iPS 細胞の比較・評価法をめざして}

研究者は、iPS 細胞どうしの比較や、iPS 細胞と ES 細胞の比較もめざしている。ES 細胞は「真の標準」と見なされている。 ES 細胞は 10 年以上も研究されてきてお り、すべて胚が起源であることから、さま ざまなタイプの組織から樹立されたiPS 細 胞よりもばらつきが少ない、と考えられる からだ。

Jaenisch が最近 Cell に発表した論文で は、再プログラム化用遺伝子が切除され る前と後で、iPS 細胞の特性がどう変わつ ているか、解析結果を報告している ${ }^{7}$ 。再 プログラム化用遺伝子が残存するiPS 細 胞では、271 個の遺伝子の発現が ES 細 胞と異なっていたが、一方、再プログラ
ム化用遺伝子が除去されたiPS 細胞では、 発現の異なる遺伝子は 48 個に減ってい た。理由はわかっていない。「iPS 細胞は ES 細胞ほどには成果が得られないとか、 iPS 細胞はES 細胞とは違う、といった事 例はずいぶんあるのですが、いずれも未 発表です」とJaenisch。iPS 細胞は胚に 由来していないので、もともと独自の存在 なのかもしれない。あるいは、現在の iPS 細胞作製法が不適切なためにiPS 細胞と ES 細胞が異なっているとも考えられる。

今のところ、iPS 細胞の評価法について は研究者の意見は一致していない。最も 厳格な再プログラム化の検証方法は、再 プログラム化されたマウス細胞を胚に挿 入し、その胚を代理母に移植して、生ま れたキメラマウスを成体になるまで育て、 その体内で産生された精子や卵で健康な 子孫が生まれるかどうかを調べることであ る。つまり iPS 細胞から全く新しい胚が生 じれば、当初の細胞の生物学的設定が初 期化されたことが確認されるわけだ。

しかし、このような検証をヒトで行うこ とは倫理的に認められない。そこで、ヒト ES 細胞のアッセイを借用したものが、現 在の標準的なアッセイとなっている。すな わち、ヒト iPS 細胞を免疫不全マウスに注 入し、6〜8 週間後に奇形腫という腫瘍 を形成するかどうかを調べるのである。自 然発生する奇形腫の中には、分化した組 織の塊（例えば毛髪や骨）に成長するも のがあるが、このアッセイで移植された細 胞が iPS 細胞と認定されるには、主な種 類の組織すべてに分化している細胞の塊 を観察できることが要件となっている。た だし、外観と表面マーカーの点で完全に 再プログラム化されたように見える細胞で も、奇形腫を形成しない事例は決して珍し くない、と研究者は話している。

一部の研究者は、iPS 細胞の認定と言 うからには、奇形腫形成能の実証を要件 とすべきだ、と考えている。この分野の第 一人者であるボストン小児病院（米国マ サチューセッツ州)の George Daley は「あ 


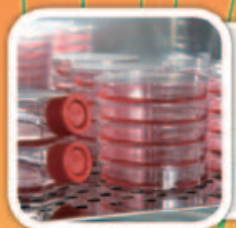

2006 年 8 月 山中伸弥が、 4 種類の遺伝 子を用いて、マウスiPS 細胞 (人工多能性幹細胞) を初め て作製した

2007 年 6 月 マウス iPS 細胞をもとに全種類の細 胞を作製できることが実証された ${ }^{2-4}$ 。 包

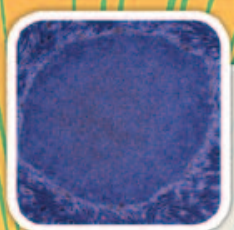

2007 年 $11 \sim 12$ 月 ヒト細胞に多能性が誘導 された ${ }^{16-18}$ 。

がん遺伝子 c-Myc なしでも再 プログラム化できることが実証 された 19,20

\section{著作権等の理} 由により画像を 掲載することが できません。

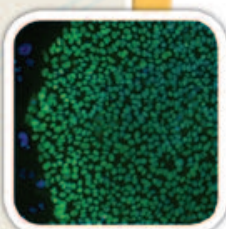

iPS 細胞でマウスの鎌状 赤血球貧血が治癒した 12

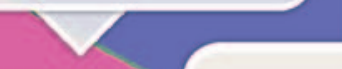

2008 年 8 月 ヒト iPS 細胞が複数種類の疾患 の患者から作製された 9,10 。

著作権等の理 由により画像を 掲載することが できません。

\section{著作権等の理 由により画像を 掲載することが できません。 \\ 2008 年 9 10月 2 つの研究グループが、検 出可能な DNA 組込みなし にマウス細胞の再プログラ ム化を行った 21,22 。}

\section{8 年 12 月}

神経変性疾患患者由来の iPS 細胞により、 シャーレ上での疾患モデル作製が可能なこと が示唆された

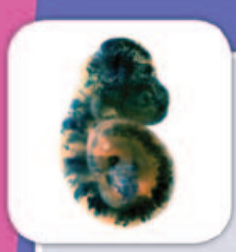

2009 年 3 月

再プログラム化用遺伝子が iPS 細胞から除去された 5 -

遺伝子組込みを行わずにヒトiPS 細胞が再プログラム化された 8
著作権等の理 由により画像を 掲載することが できません。
る一定の水準を確保しなければ、文献が 混乱する」と言う。特に、この分野は始まっ たばかりだし、手法も開発段階にある状 態なので、“ES 細胞に典型的な何々のマー カーを発現しているから iPS 細胞だ”と認 定するのは危険だ、と彼は言う。「幹細胞 性（stemness）の性質を何かしら備えて いれば iPS 細胞と呼ぶとすれば、どういう ことになると思いますか。iPS 細胞という 用語が高潔さを失い始めます」とDaley は警告する。

\section{実用化をめざした課題}

一方、現実問題として、1つの細胞株から すべてのタイプの細胞に分化できるかどう かが問題とされない場合もある。例えば、 奇形腫を形成できないが、肝細胞に分化 する傾向が非常に強い iPS 細胞は、肝疾 患モデルの作製には適切で、臨床使用に おける安全性も高い可能性がある。それ に奇形腫アッセイは多額の費用もかかる、 とオンタリオ・ヒト iPS 細胞研究所（カナ ダ、トロント) の William Stanford は言 う。彼の研究グループは、トロント小児病 院の患者から疾患特異的な細胞株を作製 しており、細胞株を作製するための試料よ り、再プログラム化のために提出される 試料の方が多くなることを既に予想してい る。「作製する細胞株を減らして、すべて の細胞株について奇形腫試験を行うべき か、それとも、作製する細胞株を増やす ベきなのかを議論しました」と彼は言う。 その結果、作製する細胞株を増やすこと に決めた。Stanfordらは、分化初期にお ける遺伝子発現試験と in vitro 試験を用い て再プログラム化細胞の多能性を評価す るが、それ以上の特性分析については、 原則として、後にその細胞を使用する個々 の研究室に委ねることにしたのだ。

iPS 細胞自体の評価のほかにも、iPS 細 胞から作製され、細胞治療、薬剂スクリー ニングやその他の用途に利用できる可能 性のある分化細胞を、厳格かつ長期的に 評価することをめざした研究も進められて
いる。均一な分化細胞試料を入手するの が難しいため、この種の評価に関する研 究論文はいまだに発表されていない、と Jaenisch は話す。それでも、薬剤スクリー ニングや疾患モデルの作製の際に、研究 者は、iPS 細胞由来の二ューロンや心筋細 胞が、正常な脳や心臓の細胞と同じよう に老化し、病気にかかることを覚悟してお く必要はあるだろう。また、細胞治療の 際には、研究者は、細胞が安定しており、 腫瘍を形成する恐れのあるiPS 細胞の残 りが含まれていないことを確認できなけれ ばならない。この腫瘍形成の可能性につ いては、ES 細胞でも評価が行われている。

このような評価が行われたiPS 細胞で あっても、臨床使用までには、いくつかの 非常に厄介な問題が残る。規制当局者に 対しては、iPS 細胞のリスクが許容できる 程度に低く、しかも移植された細胞が体 内で生存し、疾患に冒された脳や膵茞の 機能を実際に増進する可能性があること を、納得させる必要があるわけだ。この 1 月にヒト ES 細胞に由来する細胞の臨床 試験が承認されたが、ヒト ES 細胞が初め て作製されてから 10 年以上の時が流れて いる。遺伝子組換えをせずにiPS 細胞を 作製できるようになった今、臨床試験承認 までの期間は相当に短縮されるかもしれ ない。山中は、iPS 細胞が $3 \sim 4$ 年以内 に薬剂スクリーニングと薬剤毒性試験に広 く用いられるようになると考えており、10 年後には臨床試験が行われることを期待 している。

こうした研究の相当部分は、主として企 業が手がける可能性が高く、既に数社が、 iPS 細胞の実用化分野で市場独占を狙つ ている。新興のバイオテクノロジー企業 iZumi Bio 社（米国カリフォルニア州サウ スサンフランシスコ）の最高経営責任者 John Walker は、多くを語らないが、現 状では、細胞治療ではなく薬剤の試験に 重点を置いた事業展開を行うことを明ら かにした。同社は、ウィスコンシン大学卒 業生研究財団（米国マディソン）などとと 
もに、iPS 細胞とiPS 細胞作製法に関する 知的財産権訴訟を提起した。iPS 細胞の 作製法が次々と発表されるにつれて、知 的財産権の状況は「ヒ卜 ES 細胞の 10 倍 も複雑化している」とカリフォルニア大学 バークレー校法律·経営·経済センター ( 米 国カリフォルニア州）のディレクターKen Taymor は明かす。

科学の状況もますます複雑化している。 生物学者は、ある 1 つのタイプの分化細 胞を別の分化細胞に転換するには、いっ たん ES 細胞のような多能性状態に戻さな ければならない、と長い間考えてきた。と ころが、最近の研究報告では、多能性状 態に戻らずに 1 つのタイプの細胞から別 のタイプの細胞に直接転換することが可 能だとされた。この 2008 年の研究成果 で大いに称賛されたのが、ハーバード大 学の発生生物学者 Doug Melton である。 彼は、膵臓細胞にいくつかの膵臓遺伝子 を挿入すると、インスリン産生 $\beta$ 細胞の 外観を帯び、その機能を果たすように変 わることを実証した ${ }^{14}$ 。

再プログラム化の進む方向が「逆向き」 か「横向き」はさておき、研究者は、その 過程の解明をめざしている。そもそもこの 点が未解明だったので、功成り名を遂げた 科学者の多くが、iPS 細胞の分野に参入し たのだった。1950 年代の核移植による力 エルのクローン作製や 1996 年のクローン ヒツジの「ドリー」がなければ、再プログ ラム化の実験に取り組もうとは思わなかっ た、と山中は述懐している。それ以前は、 遺伝子が不可逆的に不活化し、あるいは 細胞の発生が進むと切除されるのではない か、と一部の研究者は考えていた。成体細 胞から作られたクローンであるドリーの研 究で、たとえ哺乳類の分化細胞であっても、 遺伝子が無傷のまま保持され、再プログラ ム化できることが明らかになったのだった。

\section{再プログラム化過程の解明が力ギ}

再プログラム化の概要は、既に判明して いる。細胞内のクロマチンという DNA と
タンパク質の複合体において DNA とタン パク質のもつれがほどかれ、そしてェピ ジェネティックな目印が再編成されて、分 化細胞で活性化していた遺伝子の発現が 抑制され、ES 細胞で活性化する遺伝子か 発現するようになる。こうして発現した遺 伝子は、大量のタンパク質を動員し、細 胞内機構を別の状態に変化させる。これ らの各段階が、いつどのように起こるのか については、精力的な研究活動にもかか わらず、なお解明には至っていない。iPS 細胞の研究が成熟して、この点の研究が 重点的に進められるようになることを、多 くの研究者が望んでいる。iPS 細胞を使え ば、「再プログラム化の実際の仕組みを探 究できます。この論点は、今から 50 年前 に提起されたものですが、今も手かがリ はありません」とHochedlinger は話す。

iPS 細胞があるからといって、問題の解 明が楽になるわけではない。一例をあげ れば、目的の細胞を正しく単離することが 難しいのである。一般に、iPS 細胞の作 製実験で、再プログラム化の成功率は細 胞 1000 個中 1 個にも満たない。たとえ 多能性遺伝子が活性化していても、一部 の細胞は、分化状態にとどまっている ${ }^{15}$ 。 「中間的な状態が解明されていないこと が問題なのです」。こう話すのは、カリフォ ルニア大学ロサンゼルス校の細胞生物学 者 Kathrin Plathである。彼女は、遺伝 子発現解析と細胞形態解析によって、完 全な再プログラム化の途中で立ち往生し ているように見える細胞の一部を調べてい る。「部分的に再プログラム化された細胞 は、その由来にかかわらず、どれも非常 によく似ています。これが実際の再プログ ラム化過程で生じる正真正銘の中間体な のか、それとも脇道にそれてしまったもの なのか、誰にもわかりません」とPlath。

再プログラム化過程の解明は、単なる 学究活動ではない。さまざまな細胞状態 や細胞が 1 つの状態から別の状態に移行 する過程を解明すれば、こうした細胞の 移行を支障なく誘導する方法や、治療に
必要なタイプの細胞を作製する方法の改 良に役立つかもしれないからである。

組み換え DNA や RNA 干渉といった生 物学の研究分野がスタートした時も、今 回のように息もつけない時期があった。こ うした時期を知る研究者は、現在のすさ まじいペースや激しい競争が徐々におさ まる可能性が高いと予想している。再プ ログラム化の方法を大急ぎで最適化しよう という動きはなくなり、科学者の関心は、 特定のタイプの疾患やより基礎的な研究 テーマに枝分かれしていくだろう、と南力 リフォルニア大学幹細胞・再生医療研究所 （米国ロサンゼルス）の Martin Pera 所 長はみている。「研究活動は多様化し、共 同研究が多くなると思います」と彼は言う。 共同研究が多くなるかどうかは別とし て、iPS 細胞をめぐる競争は、新たな、そ して、より知的に報われるかもしれない段 階へと向かって進んでいる。これまでは「と にかく技術、技術、技術でした。でも興味 深い研究テーマの解明に取り組む段階が 近づいています。特に難題となるのは、生 物学的な論点だと思います」と Jaenisch は話している。(菊川要 訳)

Monya Baker は、Nature Reports Stem Cells の エディター。

1. Takahashi, K.\& Yamanaka, S. Cell126, 663-676 (2006).

2. Okita, K., Ichisaka, T. \& Yamanaka, S. Nature 448, 313-318 (2007)

3. Wernig, M. etal. Nature 448, 318-324 (2007).

4. Maherali, N. etal. Cell Stem Cell1, 55-70 (2007)

5. Woltjen, K. etal. Nature 458, 766-770 (2009).

6. Kaji, K. etal. Nature 458, 771-775(2009).

7. Soldner, F.etal. Cell136, 964-977 (2009)

8. Yu, J.etal. Science advance online publication doi:10.1126/science.1172482 (26 Mar 2009).

9. Park, I. H.etal. Cell134, 877-886 (2008)

10. Dimos, J. T.etal. Science 321, 1218-1221 (2008).

11. Ebert, A.D. etal. Nature 457, 277-280 (2009).

12. Hanna, J. etal. Science 318, 1920-1923 (2007).

13. Wernig, M. et al. Proc. Natl Acad. Sci. USA 105, 5856-5861 (2008)

14. Zhou, Q., Brown, J., Kanarek, A., Rajagopal, J. \& Melton, D. A. Nature 455, 627-632 (2008).

15. Mikkelsen, T. S. etal. Nature 454, 49-55 (2008)

16. Yu J. etal. Science 318, 1917-1920 (2007).

17. Takahashi, K. etal. Cell131, 861-872 (2007).

18. Park, I-H. etal. Nature 451, 141-146(2008).

19. Wernig, M., Meissner, A., Cassady, J.P. \& Jaenisch, R. CellStem Cell 2, 10-12 (2008)

20. Nakagawa, M. etal. Nature Biotechnol. 26, 101-106 (2008).

21. Stadtfeld, M., Nagaya, M., Utikal, J., Weir, G. \& Hochedlinger, K. Science 322, 945-949 (2008).

22. Okita, K.,Nakagawa, M., Hyenjong, H.,Ichisaka, T.\&Yamanaka, S. Science 322,949-953(2008) 